\title{
Individuality as an educational project: Kilpatrick, curriculum theory, teacher education
}

La individualidad como un proyecto educativo: Kilpatrick, la teoría del curriculum y la formación del profesorado

\author{
L'individualité comme projet éducatif : \\ Kilpatrick, la théorie des programmes, l'éducation des enseignants
}

\author{
William F. Pinar \\ University of British Columbia, Canada
}

\begin{abstract}
Internationally renowned teacher educator Anne Phelan argues that teacher education must now be concerned primarily with the teachers' subjectivities, specifically with teachers' capacities for freedom of expression, thought, and action. In this essay, I juxtapose the "project method" associated with the US progressive educator William Heard Kilpatrick with Phelan's call for cultivating teachers' subjective capacities, providing one method for reconceptualizing teacher education as primarily subjective. In so doing, I continue the ongoing conversation between teacher education and curriculum theory in which Phelan is now so powerfully participating.
\end{abstract}

Key words: teacher education, curriculum, project method, William Heard Kilpatrick.

\section{RESUMEN}

Anne Phelan, la renombrada formadora de profesores, señala que la formación de profesores debería ahora preocuparse principalmente de las subjetividades de los profesores, especialmente de las capacidades de los profesores para la libre expresión, pensamiento y acción. En este trabajo yuxtapongo el "método de proyectos" asociado con el educador progresista estadounidense William Heard Kilpatrick con el llamado de Phelan para cultivar las capacidades subjetivas de los profesores, proporcionando un método para la reconceptualización de la formación de profesores principalmente subjetiva. Para tal fin 
continúo con la conversación entre formación de profesores y la teoría del curriculum en la que Phelan está actualmente participando con fuerza.

Descriptores: formación de profesores, curriculum, método de proyectos, William Heard Kilpatrick.

\section{RESUME}

Anne Phelan, éducatrice d'enseignants de renommée internationale, soutient que l'éducation des enseignants doit désormais s'occuper premièrement des subjectivités des enseignants, et spécifiquement de leurs capacités de liberté d'expression, de pensée et d'action. Dans cet article je juxtapose la méthode de projet associée avec l'éducateur progressiste américain, William Kilpatrick, et l'appel de Phelan à cultiver les capacités subjectives de l'enseignant en fournissant une méthode pour ré-conceptualiser l'éducation des enseignants comme étant subjective d'abord. Pour ce faire, je continue la conversation en cours entre l'éducation des enseignants et la théorie des programmes à laquelle Phelan participe si puissamment présentement.

Mots clés : l'éducation des enseignants, le programme, la méthode de projet, William Heard Kilpatrick.

"Whatever else education does it must work to build individuality." William Heard Kilpatrick (1930, p. 101)

"To be educational," Anne Phelan (2015) explains, "teacher education must be primarily concerned with the teacher's subjectivity, that is, with the teacher's freedom of expression, thought, and action" (p. 4). In saying so, she is "not arguing that subjectivity can or ought to be produced through teacher education" (ibid.). On that point, Phelan breaks ${ }^{1}$ from a long line of educational theorists who felt otherwise, including the American ${ }^{2}$ pragmatist William Heard Kilpatrick, ${ }^{3}$ whose project method is the subject of this theoretical reflection on teacher

\footnotetext{
${ }^{1}$ Evidently, the programmatic production of subjectivity is not completely out of the question, as it implied (if negatively) in another passage: "Something tremendously important is lost in the process of objectification," Phelan (2015) allows, "and it relates to the kind of person that is produced" (p. 14). And one subheading suggests a causal (if complex and perhaps reciprocal) relation between teaching and subjective formation: "Teaching subjects, shaping subjectivities" (p. 67).

${ }^{2}$ It matters that Kilpatrick was an American, as his embrace of individuality represented not only his immersion in the early twentieth-century progressive movement in America (for a history, see Cremin, 1961), but also, I suspect, a contradiction of individuality's obliteration in the racism of the American South, where Kilpatrick was born, came of age, and taught in the public schools (see Note 3). As Phelan (2015) knows, place and time matter; she laments "the poverty of place in teacher education" (p. 75), and she situates her case studies in specific places - for example, Austria, Canada, and Ireland in specific historical moments.

${ }^{3}$ Born in 1871 in Georgia, Kilpatrick majored in mathematics at Mercer University in Macon, Georgia, where he also studied Latin and Greek. After graduate study at Johns Hopkins, he returned to serve as a teacher and principal in the
} 
education: what is at stake, when, and why.

While it hardly harmonizes answers to those questions, attuning ourselves to time and place can prompt us to reply to them, theoretically and practically, even when what Phelan calls a "culture of objectification" (p. 13) disables us from discerning the links among what we think and feel and (do not) know. ${ }^{4}$ Those links can be obscure, of course, and not necessarily causal, but even in correlation or free association we can learn from our experience - a constant, I suggest - in the complicated conversation that is the curriculum. ${ }^{5}$ I juxtapose Kilpatrick with Phelan to continue the ongoing conversation between teacher education and curriculum theory that Phelan has now made explicit.

In her conception of teacher education curriculum, Phelan foregrounds the teacher's freedom, and in terms Kilpatrick would embrace - "individuality, that is, originality, creativity, and the capacity for dissent"; she underlines that such freedom is "always relational - at once socially structured and historically primed" (p. 1). As we will see, Kilpatrick too appreciated social structure and historical attunement; his emphasis upon individuality was associated with the American project of democratization, which included the production of citizens with democratic subjectivities, subjectivities that recognized others as human beings, not racialized others. ${ }^{6}$

Phelan characterizes "subjectivity" as an ongoing "event rather than a project of completion" (p. 3), language Kilpatrick did not use but an idea - that the "teaching subject is always in 'a state of becoming' and never fully realized" - he would appreciate. Such subjectivity, she adds, "is only possible in a world of plurality and difference." It was such a world that racism denied and against which Kilpatrick's "individual" would be produced. No isolated creature, Kilpatrick's "individual” came to form relationally, working with others, engaged in projects that, while teacher-led, were also collectively determined - curriculum, in Phelan's Arendtian phrasing, as “a space of freedom where the newcomer can reveal her singularity through speech and action, be witnessed by others, and thus make her appearance

public schools of Georgia. Then, after a few years as professor of mathematics and acting president at Mercer - from which he resigned after being accused of atheism - Kilpatrick went to study at Teachers College, Columbia University, where he taught for 27 years, attracting more students than any other professor, some 35,000 (Ravitch, 2000, p. 178; Westbrook, 1991, p. 504).

"One consequence of objectification is "presentism," an incapacity to experience time. Historical study is an antidote (see Bruno-Jofré \& Johnston, 2014, p. 4; Pinar, 2012, p. 225).

${ }^{5}$ See Pinar 2015b, pp. 109-125. Learning from experience requires non-coincidence with what is - Phelan (2015) focuses on "estrangement" (p. 85), a similarly detaching concept - enabling subjective freedom (positive and negative), what she characterizes as "quintessentially education," namely "a concern with the freedom associated with selfformation (imbricated in the social and historical) through knowledge and experience" (p. 9). Invoking a different vocabulary, Kilpatrick commits to the same set of ideals.

${ }^{6}$ This is my language here; subjectivity is not a term with which Kilpatrick worked but which he would not be, I think, unhappy. And while he doesn't explicitly link individuality (or democratic subjectivity) with anti-racism, it seems to me implied, and it becomes almost explicit in much later historical studies of gender in the US. See, for instance, Kimmel, M. S. (1996). Manhood in America: A cultural history. New York, NY: Free Press, (p. 333). For an international perspective, see Frank, B. W., \& Davison, K. G. (Eds.). (2007). Masculinities and schooling: International practices and perspectives. London, ON: Althouse Press. 
in the world." In such a conception of curriculum, Phelan points out, the "ethical" is paramount, as is "the political" (p. 5).

The two become blurred in Kilpatrick's embrace of education as the laboratory of democracy, a Deweyan conception the great philosopher had pretty much abandoned 7 by the publication date of Kilpatrick's "The Project Method" (1918). That article "caused such an immediate sensation that the Teachers College Bureau of Publications was obligated to distribute an astounding 60,000 reprints" (Kliebard, 1986, p. 159). Those reprint requests were not confined to the United States.

In Canada, the "project method" is credited with being "the basis for so-called enterprise teaching, whereby the curriculum was organized around units of study, or enterprises... widely advocated across Canada" (Tomkins, 1986, p. 142). ${ }^{8}$ In the United States, the project method is acknowledged as inspiring numerous progressive experiments, as Diane Ravitch - before her conversion to anti-school reform activism ${ }^{9}$ - complained. ${ }^{10}$ In South Korea, the concept was introduced some five decades ago. ${ }^{11}$ The concept remains relevant in China's contemporary reform's encouragement of a "curriculum of life-inquiry" (Zhang Hua,

\footnotetext{
${ }^{7}$ See Westbrook (1991), p. 192.

8 The curriculum for the 1907 Bachelor of Pedagogy degree at Queens University "fully embraced the pedagogical tendencies of the time, while having a degree of eclecticism. It included John Dewey and William James, thus highlighting pragmatism, William Kilpatrick in the line of Dewey, but also Herbert Spencer and Edward Thorndike" (Bruno-Jofré \& Cole, 2014, p. 77). Kilpatrick and the pragmatists' representation in Canada's teacher education curriculum then spread westward. "The method took firmest hold in Alberta during the 1930s," Tomkins (1986, p. 142) tells us; but, he adds later, even "by 1922, Saskatchewan normal school students were receiving instruction in W. H. Kilpatrick's project method, the most publicized pedagogical innovation of American progressivism during the inter-war years," and "the centerpiece of curriculum revision during the 1930s" (p. 190). For an in-depth study of progressivism's reception in Ontario, see Christou, T. M. (2012). Progressive education: Revisioning and reframing Ontario's public schools, 1919-1942. Toronto, ON: University of Toronto Press.

${ }^{9}$ See Pinar (2012), p. 198ff.

${ }^{10}$ In Ann Arbor, Michigan, for instance, elementary schools were converted into "activity schools in which pupil experience rather than subject matter was emphasized. The transformation was led by Edith Baker, a progressive supervisor who had studied at Teachers College in the early 1920s... She believed in joint teacher-pupil planning of the day's activities. Under leadership, academic subjects were integrated, textbooks were eliminated, and even reading classes were discontinued for a time because reading was taught in 'situations' rather than in specific classes" (Ravitch, 2000, p. 243). Ravitch also depicts Kilpatrick-inspired progressive experiments in California and New York City (p. 243, 249). At one point Ravitch qualifies her critique: "When used by teachers who saw activities as a better way of teaching subject matter rather than as a way of avoiding it - as means to an end rather than ends in themselves - the activity program was valuable. But in the hands of teachers who lacked subject matter knowledge, the activities became ends in themselves" (p. 244). For Kilpatrick, it was not either/or; for him working with and through the school subjects, educational activity could contribute to the formation of individuality.

${ }^{11}$ In the early 1960s, the Deweyan theory of "education as experience" was "officially adopted in South Korea, and curriculum was defined as 'all learning activities which students experience under the guide of the school.' William Kilpatrick's Project Method was introduced to teachers, and peer group problem solving was encouraged to meet students' individual differences. However, curricular decisions were still made by the central government, and classes still focused on entrance examinations" (Lee, 2003, p. 546). Here, we see the tension between progressive practice and standardized assessment, evident also in China and, Phelan notes, Canada (see Note 36 ).
} 
quoted in Pinar, 2014, p. 14) ${ }^{12}$ as Kilpatrick's concept emphasizes lived educational experience and not only in schools. ${ }^{13}$

When "The Project Method" appears in 1918,14 the Great War is ending, but Kilpatrick, like many of his fellow progressives, remained embattled, determined to replace "traditional" education ${ }^{15}$ - instruction dominated by recitation and learning by memorization - with "progressive" education devoted to the formation of democratic citizens. Kilpatrick (1918) summarized traditional education as a "regime of coercion" that meant meaningless learning, what he ridiculed as "aimless dawdling" - a term that has disappeared from everyday English usage but means idle, wasted activity ${ }^{16}$ - that presumably produced "pupils" who became "selfish individualists" (p. 18). ${ }^{17}$ That is the crucial consideration: the consequence of

\footnotetext{
${ }^{12}$ The project method was "intended to serve Dewey's social purpose by creating a school environment more nearly typical of life itself than that of the traditional curriculum." (Tomkins, 1986, pp. 190-191, emphasis added). Regarding his students at Teachers College, Taba (1962) quotes Kilpatrick as insisting that "they learn what they live" (p. 160).

${ }^{13}$ For some enthusiasts, Kilpatrick focused on schools too much. Caroline Pratt (1926), for instance - while acknowledging that "we seem to be working out a 'project' method, perhaps" - drew an "essential difference between our method and any project method with which I am familiar" (p. 332). For her and her colleagues "it is a method which can be applied to adult social undertakings and is often applied to informal undertakings. It is a method of learning to live and work together."

${ }^{14}$ That is the date of publication, but Harold Rugg (1926) has observed that the idea long preceded Kilpatrick's formulation of it: "In other words, the essential basis of the so-called 'educational project' was in effective operation in the F. W. Parker School, as it was in the University of Chicago Laboratory Schools, for years before the development of the systematic philosophy of the project method" (p. 99).

${ }^{15}$ Kilpatrick acknowledges that by 1918 traditional education has been replaced in some schools, including in childcentered schools of which he was critical: "Some in reaction [to traditional education] have resorted to the foolish humoring of childish whim. The contention of this paper is that wholehearted purposeful activity in a social situation as the typical unit of school procedure is the best guarantee of the utilization of the child's native capacities now too frequently wasted" (1918, p. 18).

${ }^{16}$ The concept of activity becomes associated with the project method, widely practiced and widely criticized, even by Kilpatrick's student Hilda Taba (1962): “Unfortunately, this principle of active learning was in practice often reduced to manipulative activity, such as making clay animals in connection with the farm unit, building a grocery store in connection with the grocery unit ... Such 'activity programs' have often failed to produce any 'doing' except following directions and often have forgotten that one purpose of the 'activities' is to provide the conditions for reflective thought, and further, that reflective thought itself is active learning. Recently the principle of active learning has been restated under the term of learning by discovery" (p. 280). By that term, she is referencing the early work of Jerome Bruner.

${ }^{17}$ Probably he does not mean here what I would term narcissists, those who are self-absorbed but not individuated, but he would include contemporary entrepreneurs who affirm "individualism" for the sake of social and economic exploitation. Kilpatrick associated "selfish individualists" with the past, "the remnants of frontier individualism which left each man to shift for himself" (Kilpatrick 1930, p. 38). Being an individual requires relationships, a fact Kilpatrick does not emphasize in "The Project Method" but does so on other occasions. In his 1928 lecture at the University of North Carolina, for instance, he affirmed "we are in fact all members one of another" (p. 94). Relationality acknowledged, Kilpatrick issued what he termed a "plea ... for the creation and preservation of individuality. Such a conception of individuality as here used may be asserted either of a person or of a group (at the best it requires both together). Moreover, this individuality must be born of its relation to the environment" (p. 11, 12). That environment, and the topic of his talk, was the American South. "The South," Kilpatrick told his listeners, "must do justice to the Negro" (p. 36).
} 
curriculum for the subjective shaping of those who undergo it. ${ }^{18}$ Recall that Dewey - Kilpatrick was an admirer - had retreated from his faith that the classroom could be a laboratory for democracy, that (in my terms) through subjective reconstruction social reconstruction could occur (and vice versa). ${ }^{19}$ Key for Kilpatrick was "purpose," indicated in the subtitle of his 1918 article: "The Use of the Purposeful Act in the Educative Process."

Indeed, by "project" Kilpatrick meant "purposeful act," emphasizing "action, preferably, wholehearted vigorous activity" (p. 3). ${ }^{20}$ Such activity, he tells us, is structured by "the laws of learning" and "the ethical quality of conduct," by which he references both "the social situation as well as to the individual attitude." He wonders if "all of these [can] be contemplated under one workable notion" (p. 4). This question leads him to consider "fundamental principles."

Confessing to skepticism of "fundamental principles," Kilpatrick finds himself wondering: could there be "another way of attaining unity?" (p. 4). He points to "method" - and in contrast to "concrete procedure," although this distinction fades elsewhere (see Note 31) wherein such "unification" might reside, a "unit of conduct" that could be "as it were, a sample of life, a fair sample of the worthy life and consequently of education?" The "unifying idea I sought," he reflected, "was to be found in the conception of wholehearted purposeful activity proceeding in a social environment, or more briefly, in the unit element of such activity, the hearty purposeful act" (ibid.).

Emphasizing the adjective, Kilpatrick christens his concept of "project," hyphenating it to underline that it conveys "something pro-jected," thereby emphasizing purposeful action (p. 4). Both individual and groups may engage in such purposeful action, and these "projects" are

\footnotetext{
${ }^{18}$ Establishing causality not merely correlation remains a challenge in educational research, as it has in social science generally (for one example, see Young-Bruehl, 1996, p. 57ff.). The 15 April 1940 issue of Frontiers of Democracy (formerly The Social Frontier) featured an article by Harlem Renaissance figure and philosopher Alain Locke who called for "intercultural studies," arguing that students needed a broader curriculum that would "promote tolerance, democracy, and humanity" (Watkins, 2006, p. 224). Locke acknowledged, however: "The school, after all, cannot alone create democracy or be primarily responsible for it" (quoted in ibid.). The faith or aspiration or "scientific" expectation that teaching and/or curriculum can produce predictable (or even yearned for) consequences remains, as we see in Phelan's demurral in the opening paragraph of this essay.

${ }^{19}$ Evidently there were occasions - among some indigenous peoples - when the project method functioned as a continuation of cultural practices, rather than their contradiction or reconstruction. In a 1944 article, Ruth Underhill had declared that Papago children traditionally "learned through activity, in a system surprisingly like our modern project method" (Reyhner \& Eder, 2004, p. 223). A 1948 article on day school methods for Sioux students by the Indian Service's associate supervisor of education, Gordon MacGregor, had noted: "The project method is exceptionally well suited to educating the Dakota because it follows their own method of learning by doing and following the example of others. By bringing the children to participate and to share in the work and the responsibility for completion of a project, this method also reinforces the training for cooperative work already begun in the family." Reyhner and Eder report that through the 1990s, the project method was "still recommended for Indian students" (p. 224).

${ }^{20}$ This is also key concept for William E. Doll, Jr. See Trueit, D. (Ed.). (2012). Pragmatism, postmodernism, complexity theory: The fascinating imaginative realm of William E. Doll, Jr. New York, NY: Routledge (p. 7).
} 
not necessarily academic: "It is clear," he writes, "that projects may present every variety that purposes present in life" (1918, p. 321). ${ }^{21}$

What is "essential" - and not necessarily "observable," he continues - is the "presence of a dominating purpose." And this "dominating purpose" may not be any narrow expression of one's will or cognitive calculation, as Kilpatrick declares that only those "activities" into which a student "puts his 'whole heart"' qualify (p. 322). That qualification would seem to make educational activity more a matter of emotion - and he does characterize the project as "essentially psychological in character." But, he qualifies, it demands "the social situation both for its practical working and for the comparative valuation of proffered projects."

Purposeful activity - not merely "drifting" (recall that "dawdling" was his earlier word choice for purposelessness) - is, Kilpatrick asserts, "the typical unit of the worthy life" (p. 322). He allows that "not that all purposes are good," but he insists "the worthy life consists of purposive activity." It is the worthy life in "a democratic society" that is, and even (more specifically) of a worthy American ${ }^{22}$ life, as he asserts: "We of America have for years increasingly desired that education be considered as life itself and not as mere preparation for later living. The conception before us promises a definite step toward the attainment of this end" (p. 323). But it is not only national identity ${ }^{23}$ and style of governance that frames his conception of the project; referencing Thorndike, ${ }^{24}$ he writes that it is its "utilization of the

\footnotetext{
${ }^{21}$ Jay (2005) reports that nineteenth-century European Romantics "stressed the importance of something called Leben, or 'life,' against the mortifying implications of excessive rationation, impersonal legalism, and mechanical causality" ( $p$. 95). Does Kilpatrick's invocation of "life" represent a trace of nineteenth-century European Romanticism?

${ }^{22}$ Certainly there have been those for whom an educational emphasis upon "experience" - "meant here both novel experimentation and learning valuable lessons from the past to be imaginatively applied to the future" (Jay, 2005, p. 266) - has been claimed as exceptionally American. Historians of the American Revolution, Jay notes, have documented how the rhetoric of "experience" animated the discourse of the founding fathers, quoting Patrick Henry: "I have but one lamp by which my feet are guided, and that is the lamp of experience. I know no way of judging the future but by the past" (p. 171). Jay also quotes the philosopher John J. McDermott, who called America a "culture of experience," and cites John E. Smith, who claimed experience as "America's philosophical vision" (p. 266). Today, and not only in America, embodied lived experience - however nationally inflected - may be in danger of being erased by staring at screens (Pinar, 2015a, pp. 179-182). Sagely, Bruno-Jofré and Johnston (2014) question "the educational need" for "attention" to technology in teacher education (p. 8). Indeed, the only curricular "attention" I would accord technology is historical and critical (Pinar, 2012).

${ }^{23}$ Affirmation of America was no expression of nationalism, at least if we accept his statement - made ten years laterthat: "The spirit of nationalism ... becomes ... increasingly ill adapted to the needs of an interdependent world" (Kilpatrick, 1930, p. 26). Not only ill-adapted, nationalism - when regionalized in the American South - is poisonous, as Kilpatrick makes clear: "Fundamentalism" and "the Ku Klux movement" are "manifestations of excessive nationalism." (p. 33). But in his opposition to anti-democratic forces, he was not tempted to indoctrinate: "Democracy, to be itself, cannot indoctrinate even itself" (Kilpatrick quoted in Perlstein, 2000, p. 62).

${ }^{24}$ On occasion, Kilpatrick references Thorndike (1918, p. 7) and uses stimulus-response language (p. 13)-contradictory conceptions for me, but one that Tomkins (1986) manages to align: "The essence of the [project] method was the reorganization of the curriculum in to a succession of projects which, by emphasizing 'purposeful activity' consonant with the child's own goals, would enhance learning through using Thorndike's concept of positive reinforcement" ( $p$. 190). Harold Rugg (1926) too seemed to see continuity not contradiction: "Professor Kilpatrick has exerted a widespread influence on the vitalizing of elementary-school instruction... He has integrated into a systematic philosophy of educational method the essential ideas of biological evolution and of dynamic psychology as developed by James, Thorndike, Woodworth, and others" (p. 103). Later, in his foreword to Hilda Taba's The Dynamics of
} 
laws of learning" (Kilpatrick, 1918, p. 7). Are these "laws" intrinsically democratic and American, as his assertion implies?25

One such "law" is learning's encouragement of new learning. "Any activity," Kilpatrick cautions, "which does not thus 'lead on' becomes in time stale and flat. Such 'leading on' means that the individual has been modified ${ }^{26}$ so that he sees what before he did not see or does what before he could not do" (p. 12). Indeed, he asserts that "the value of any activity - whether intentionally educative or not - [is] its tendency directly or indirectly to lead the individual and others whom he touches on to other like fruitful activity." How Kilpatrick would distinguish such "fruitful" engagement from, say, sheer busyness is not obvious, except we could not rely (as noted earlier) on observation. It could be the intensity - indicated earlier by the invocation of "wholehearted" - and the scale of the project that provides guidance, as he suggests: "It is the special duty and opportunity of the teacher to guide the pupil through his present interests and achievement into the wider interests and achievement demanded by the wider social life of the older world" (p. 12). ${ }^{27}$ While at first blush we could say he is endorsing a cosmopolitan outlook, is he not also flirting with Bobbitt's (1918) conception of curriculum as composed of adult activities?28

The conformism Bobbitt's model threatens seems absent from Kilpatrick's project, however, not only due to the latter's association of the concept with democracy but also with morality. "Speaking for myself," Kilpatrick tells us, "I consider the possibilities for building moral character in a regime of purposeful activity one of the strongest points in its favor; and contrariwise the tendency toward a selfish individualism one of the strongest counts against our customary set-tasks sit-alone-at-your-own-desk procedure" (p. 13).

Cooperatively working with others was, then, for Kilpatrick and for other US progressives, not only democratic but also moral: "moral character is primarily an affair of shared social relationships; the disposition to determine one's conduct and attitudes with reference to the welfare of the group" (Kilpatrick, 1918, p. 13). Hedging his bets, however, he allows that "in the school procedure here advocated children are living together in the pursuit

Education, he seems to shift his position. "The stimulus-response conception is reinterpreted," Kilpatrick (1932) writes, referring to what Taba achieves in her book, "so as to give it a still useful but distinctly subordinate position. Learning is conceived in far more useful fashion, relating it on the one hand to the essential purposiveness of conduct and on the other to an all-pervasive structure building" (p. xvi ). In that text, Taba (1932) suggests an even broader shift had occurred in his thought: "Dr. Kilpatrick has since modified his position on purposive learning considerably" (p. 172, n. 1)

${ }^{25}$ I have argued otherwise (perhaps most adamantly in 2012), as has Peter Taubman (2009, pp. 191-192).

${ }^{26}$ I acknowledge the genesis of my concept of "subjective reconstruction" in progressive thought, but it does not remain there, as it is influenced by psychoanalysis, especially by variants formulated by the Frankfurt School. See Pinar (2012).

${ }^{27}$ Dewey emphasized that not all projects were equal and that the teachers' professional judgment is crucial: "it is the business of the educator to study the tendencies of the young so as to be more consciously aware than are the children themselves what the latter need and want. Any other course transfers the responsibility of the teacher to those taught" (quoted in Ravitch, 2000, p. 246).

28 "There is a strong drift in public education toward this project-method of organization," Bobbitt (1918, p. 30) records. He and Kilpatrick seem almost indistinguishable when Bobbitt proclaims: "Knowing and doing should grow up together" (p. 31). 
of a rich variety of purposes, some individually sought, many conjointly." So either alone or together, purpose is to prevail; it is purposeful activity that expands the subjectivity through projects into the world. ${ }^{29}$

In these subjectively and socially focused projects, Kilpatrick positions the teacher as crucial. It is she (or he) who emphasizes one or the other, helping children to cultivate their capacities for judgment by deciding the project's form: not only working alone or in a group but presumably the matter of topic, too. "Under the eye of the skillful teacher," he advises,

the children as an embryonic society will make increasingly finer discriminations as to what is right and proper. Ideas and judgment come thus. Motive and occasion arise together; the teacher has but to steer the process of evaluating the situation. The teacher's success - if we believe in democracy - will consist in gradually eliminating himself or herself from the success ${ }^{30}$ of the procedure. ${ }^{31}$ (p. 13)

Today, however, with predatory corporations ${ }^{32}$ eager to remove the teacher altogether, in my reactivation of Kilpatrick I de-emphasize this destination. It's true, independence of thought and action is laudable, but such ideals are always in context, embedded in activity, structured by ethical commitments to some and by political demands made by others. ${ }^{33}$ Nor does it

\footnotetext{
${ }^{29} \mathrm{Or}$, as I phrase it, private passion is reconstructed into public service. See Pinar, W. F. (2009). The worldliness of a cosmopolitan education: Passionate lives in public service. New York, NY: Routledge (p. 153, n. 11).

${ }^{30}$ Success is not only indicated by the teacher removing herself - meaning, I suppose, that the children are selfpropelled, focused on their projects - but also by the duration of their interest. "In connection with this 'maturing,'” Kilpatrick (1918) writes, "goes a general increase in the interest span, the length of time during which a set will remain active, the time within which a child will - if allowed - work at any given project" (p. 15). Given the elimination of teacher, both intensity and duration were indicators of success. The role of developmentalism in Kilpatrick's thinking at this point isn't obvious to me, as in the conclusion he asserts "that the child is naturally active, especially along social lines" (p. 18), implying that his "procedure" is the glove that fits the hand, rather than presenting a challenge that will change children as they rise to the occasion. But clearly he has that possibility in mind too, as he adds (in that conclusion): "With the child naturally social and with the skillful teacher to stimulate and guide his purposing, we can especially expect that kind of learning we call character building" (p. 18).

${ }^{31}$ Given the distinction he draws elsewhere between "method" and "procedure," it is interesting that he here characterizes the project method as a procedure. Well under way by 1918 was the (American) effort to conceptualize curriculum development as procedural, rendered later a "basic principle" by Ralph Tyler. It's not clear in what sense the project method is procedural, given that for only one of the four types of projects Kilpatrick identifies does he specify steps. That type is "Type 1, where the purpose is to embody some idea or plan in external form, as building a boat, writing a letter, presenting a play" (1918, p. 16), and its protocol is: "purposing, planning, executing, and judging" (p. 17). He concludes this list by advocating "that the child as far as possible takes each step himself" (p. 17).

${ }^{32}$ K-12 Inc. qualifies (Pinar, 2013, pp. 24-28). For the network of predators, see Spring, J. (2012). Education networks: Power, wealth, cyberspace, and the digital mind. New York, NY: Routledge.

${ }^{33}$ While not specifying these mediating and contextualizing elements, Kilpatrick (1918) would seem to agree: "The continual sharing of purposes in such a school offers ideal conditions for forming the necessary habits of give and take" (p. 13). I would resist making "give-and-take" a habit, as that implies an automaticity that compulsory "collaboration" already aggravates. Purposefulness implies sometimes declining to "give-and-take," but, instead, holding one's ground, something Kilpatrick himself bravely did when he lectured in 1928 at the University of North Carolina on race. At one point, he accused the South of "mental sloth ... moral cowardice, and intellectual dishonesty" (Kilpatrick, 1930, p. 32).
} 
require the elimination of the teacher: my $\mathrm{PhD}$ mentor, ${ }^{34}$ while not shy in expressing skepticism toward my projects, never discouraged me, and it was within that almost fortyyear-long relationship that my ongoing efforts toward independence, originality, and purpose proceeded. ${ }^{35}$

Kilpatrick (1918, p. 17) does acknowledge matters of structure, physical ones such as "room furniture and equipment," even "school architecture," as well as changes in more immediate implements, among them a "new type of text-book" (p. 18), but not only materiel and artifacts. He also wants a "new kind of curriculum and program, possibly new plans of grading and promotion, most of all, a changed attitude as to what to wish for in the way of achievement." Kilpatrick knew that all is for naught unless educational evaluation changes. ${ }^{36}$ Curriculum reformers in China - and Canada - know that, too. ${ }^{37}$

Kilpatrick's claims for his project method were several and sometimes inflationary, speculating that what "this type of procedure means for democracy" is nothing less than providing "better citizens, alert, able to think and act, too intelligently critical to be easily hoodwinked either by politicians or patent-medicines, self-reliant, ready of adaptation to the new social condition that impend" (p. 18). Like China's current curriculum reform, Kilpatrick's project method - he knew - would provoke "opposition" from multiple sources: from "tradition" and "taxpayers," as well as from "unprepared and incompetent teachers," from "the absence of a worked-out procedure" and "problems of administration and supervision." "All these," he concludes, "would suffice to destroy the movement were it not deeply grounded."

\footnotetext{
${ }^{34}$ My mentor in graduate school- Paul R. Klohr - remained influential for me (Pinar, 2015b).

${ }^{35}$ Of course there have been other intellectually influential relationships in my life, but with the exception of those with Madeleine Grumet, Peter Taubman, and Alan Block, none as imprinting as Klohr's. Under the proper guidance," Kilpatrick (1918) allows, "purpose means efficiency, not only in reaching the projected end of the activity immediately at hand, but even more in securing from the activity the learning which it potentially contains" (p. 18). Notice, too, that again Kilpatrick reduces the project method to a procedure as he detaches "learning" from the "activity" itself, a move I worry supports the separation of skill from knowledge. Once totally detached, we have the world of Williamson (2013), a "future" wherein teachers and knowledge are supplanted by "a DIY self-driven culture, learning becomes endless, lifelong, and lifewide across the entire life cycle, as individuals seek out new experiences and hence more learning. Learning is repositioned by digital media culture as a lifestyle choice rather than an institutionalized process of schooling" (p. 108).

36 "Let us cease," Kilpatrick (1930) pleads, "to think of education as acquiring subject-matter, with examinations as the goal and test of the process" (p. 108). Later, he laments "that the scientific development of tests and measures has so largely tended to maintain the traditional and unsatisfactory types of objectives" (p. 113). I argue it's long-past time to abandon "objectives" altogether. The curriculum question - what knowledge is of most worth - should suffice to start and redirect the complicated conversation that is the curriculum.

${ }^{37}$ During the project "Curriculum Studies in China" (see Pinar, 2014) there were numerous acknowledgements that standardized examinations undermine, if not block altogether, China's curriculum reform. A similar tension between experimentation and examination obtains in Canada: "Canadian educators are now witnessing a generation of education reform," Phelan (2015) observes, "that calls for seemingly more progressive approaches to teaching and learning (e.g. Ontario's full-day Kindergarten (FDK) and Open Minds, Healthy Minds (OMHM) policies and British Columbia's Education Plan) yet retains previous commitments to accountability and high student achievement" ( $p$. 155).
} 


\section{Opposition}

Not among the opponents Kilpatrick anticipated were other progressives. On occasion, Kilpatrick (1930) could seem anti-intellectual, asserting at one point that "we must stop thinking of education as merely book knowledge and school skills authoritatively handed down. Books and skills at best are but means" (p. 107). His qualification of that devaluation "books and skills will be needed and in the end will be more fully mastered than now" - didn't go far enough, many thought, as he seemed sure that they "are but means and thus quite secondary to the enriching of life." Such statements allowed Cremin (1961, p. 220) to write: "in his unrelenting attack on subject matter 'fixed-in-advance,' ultimately discredits the organized subjects and hence inevitably shifts the balance of Dewey's pedagogical paradigm toward the child. The resultant child-centered emphasis calls to mind the very position Dewey himself rejected, first in The Child and the Curriculum (1902) and later in Experience in Education (1938)." From being at odds ${ }^{38}$ with Dewey, later students of the Progressive Era in the United States are even harsher, alleging that the project method "may have caused more damage to progressive education, particularly to its image, than virtually any other curricular or instructional innovation" (Kridel \& Bullough, 2007, p. 30). That allegation seems entirely excessive; Kridel and Bullough offer no evidence. ${ }^{39}$

In the United States, then, the controversy over the project method centered over the centrality of the school subjects in the curriculum. There are countless commentaries but I rely on Robert Westbrook (1991), who judges that it was Kilpatrick's "privileging” of the children's "purposes" and the subsequent "subordination of subject matter to them" that "troubled Dewey" (p. 504). Westbrook adds that Dewey "agreed" with Kilpatrick that learning begins with children's interests, although he worried that any unmediated pursuit of those interests risked trivializing the curriculum. Dewey had no objection to the "project method," Westbrook clarifies, but he "insisted that projects must have as one of their goals the child's mastery of organized subjects." 40

\footnotetext{
${ }^{38}$ Tomkins (1986) tells the same tale: "Although Kilpatrick's emphasis on educative intellectual and moral experiences, which was designed to develop character in the interests of group welfare, was fully consistent with Dewey's philosophy, his excessively child-centered stance and his denigration of extrinsic 'fixed in advance' subject matter put him at odds with the great philosopher" (p. 190).

${ }^{39}$ There is an endnote following the claim, but the references seem general, not specific in support of their allegation. Even the great curriculum theorist Dwayne E. Huebner (1999) feels no obligation to offer evidence or argument when it comes to this issue, assuming that readers will agree that Kilpatrick was guilty of "romanticizing the child" (p. 250). It should be clear from my copious quotation of Kilpatrick that, on the contrary, he was determined to shape the child through activity into what he or she was not: an individual. There is no romanticizing the child in that conception. On the contrary, it seems a secular version of Christianity's proclamation of original sin and salvation through good works. ${ }^{40}$ So Ravitch (2000) is not wrong, but still exaggerates the differences between Kilpatrick and Dewey when she insists that for Dewey "projects and activities were devised to achieve a curricular purpose" (p. 182). As Westbrook notes, mastery of subject matter was one but not the only goal of projects. Taba (1932) warned "proponents of the childcentered school and of the project method ... that by tearing down the structure of segregated subjects and by reorganizing educative experience around the units of work or centers of interest, learning is not necessarily made dynamic, in the sense that all that is learned becomes effective in the conduct of the learner and can be put to use in
} 


\section{Subjective reconstruction}

"How is individuality built?" Kilpatrick asks. His too-brief answer invokes art, not engineering: "a back and forth process between artist and situation in which both undergo transformation. As the artist molds the situation into new form he re-builds also himself" (1930, p. 12). Here is acknowledgement of the reciprocity of self and situation, as Madeleine Grumet phrased it (see Pinar et al., 1995, pp. 377-378). Grumet stresses duration as supportive of reciprocity; one must stay in a relationship or situation in order to participate in its reconstruction. Projects may have no set timeline, but implied in both Kilpatrick and Grumet is that self-formation through academic study takes time.

It is the "absence" of individuality "which we now so much deplore," Kilpatrick complained (1930, p. 16). "A sameness rules," he continued, as "the meanings of things have been merely copied. Integration has been exactly overlooked." That term "integration" has multiple meanings, but in the context of individuality the relevant one is "the process of coordinating separate personality elements into a balanced whole," a concept similar to "synthesis" in the method of currere. ${ }^{41}$ Here he is discussing individuality to an audience at the University of North Carolina in 1928, and so "integration" could imply not only subjective coherence, but interracial harmony, two projects that can be considered in tandem. 42 "The building of such an individuality," Kilpatrick knows, "is task enough to call forth all latent endeavors."

Science is no friend of individuality, dedicated as it is to nomological laws, and within education standardizing protocols - so-called "evidence-based" determinations of "what works" - stipulate sameness. ${ }^{43}$ Within such conceptions of "science" and "education" there is, Kilpatrick notes, a "small place [that] seems left for individuality" (1930, p. 70). That place is the educational project, through which, he imagined, children can express their uniqueness, discover their classmates' individualities, and shape reciprocities among caring, concern, and learning. "We are in all of this," he emphasized, "concerned with building persons, masterpieces of individuality, persons that ever grow themselves, persons that always respect a like growing in others" (p. 93). In my terms, subjective and social reconstruction are reciprocally related. 44

\footnotetext{
further learning" (pp. 253-254). Not the mastery of the school subjects but continued growth was criterion by which Taba judged the success of projects.

${ }^{41}$ Pinar (2012), p. 46.

${ }^{42}$ If one's subjective coherence includes racism, then self-shattering must follow: see Pinar, W. F. (2006). Race, religion and a curriculum of reparation. New York, NY: Palgrave Macmillan (p. 183). Subjective reconstruction includes destruction when what one has been bequeathed must be disclaimed.

43 "The new prestige of science," Jay (2005) recounts, in his history of experience, "also meant jettisoning Montaigne's preoccupation with introspection and self-discovery; to be worthy taking seriously, experience had to be public, replicable, and verified by objective instruments" (p. 40).

${ }^{44}$ See Pinar (2012), p. $207 \mathrm{ff}$.
} 
Projects are not propaganda, Kilpatrick emphasized, two years before the Counts controversy. 45 "The needed education," he emphasizes, "must aim rather more and better selfdirection," by which he means not the instrumentalization of subjectivity but its reconstruction, "self-direction which rusts meanings," which tackles its legacies critically, as reparation requires (p. 95). To a group of white Southerners listening to these words in 1928, their coded meaning is clear. For race to "rust," racist subjectivity must be shattered, from which new forms of human being can be fashioned. Those forms are to be more cosmopolitan, as Kilpatrick makes clear, enabling us "to act in the light of meanings sought and found itself ever more broadly considered, meanings which change our ways of thinking to more adequate ways and so direct our efforts along more fruitful lines." That adjective is ambiguous, but it can imply creativity as well as increased productivity. Students - as well as American culture generally, and Southern culture specifically - can become increasingly capable of creative inquiries, he felt sure, learning those skills by which they extend the range of what they know and can appreciate.

"It is this whole, the very self of the learner," Kilpatrick reminds, "that is involved in every act" (1930, p. 113). It is this very "growing" of student's "self, its present actual growing with the greatest possible promise of future growing" that for him must concern the teacher more than anything else. Herein lies Kilpatrick's conception of teacher education, I suspect. In the teacher's commitment to the student's self-formation, ${ }^{46}$ the teacher necessarily dedicates herself to her own. ${ }^{47}$

Kilpatrick's conception of curriculum includes one "unit element," the "unit of life, the experience" (p. 116). ${ }^{48}$ He underlines the educational significance of time, asserting that growth itself requires experience that "comes connectedly out of the past and leads more and more connectedly into the future. Otherwise," he warns, "the individual lacks depth and

\footnotetext{
${ }^{45}$ See Perlstein (2000); Pinar et al. (1995), p. 126. Soon after Counts issued his challenge, Kilpatrick analyzed "the social crisis" by comparing the capitalism to classrooms that "stressed extrinsic motives and individual successes" (Ravitch, 2000, p. 223). In contrast, in progressive classrooms children worked because education was satisfying. Calling for a new society with a new philosophy of life, Ravitch overstates - sensationalizes might be the more precise predicate Kilpatrick's commitment to life inquiry at the expense of schools subjects, declaring that Kilpatrick believed that the "first step in building a new society would be to get rid of academic subjects and use the schools to analyze life's problems" (p. 224).

46 This conception resonates within German traditions with which Kilpatrick would have been familiar: "Bildung is understood as a qualification for reasonable self-determination, which presupposes and includes emancipation from determination by others. It is a qualification for autonomy, for freedom for individual thought, and for individual moral decisions. Precisely because of this, creative self-activity is the central form in which the process of Bildung is carried out" (Klafki, 2000, p. 87). Can we associate this conception of "self-activity" with Kilpatrick's? Certainly he viewed "projects" as "creative self-activity." Phelan also references Bildung (see 2015, p. 85).

${ }^{47}$ There are gendered legacies and expectations at play here - specifically, culturally ingrained demands for nurturance - demands teachers of all genders must confront and, in situationally-specific ways, enact, but which are embedded in life-long commitments to cultivate - in part through caring (see Jung, in press) - one's subjective formation as a teacher, as a person (see Miller, 2005, pp. 74-75), and as a citizen (Phelan, 2015, p. 155).

${ }^{48}$ The starting point of curriculum construction for Kilpatrick "was to learn what children were interested in and know how to stimulate these interests," not with "subject matter selected in advance" (Ravitch, 2000, p. 181). The centrality of subject matter in curriculum does distinguish Kilpatrick from Dewey, as noted earlier.
} 
bearing." The project method is, in this sense, a method for reconstructing "selfish individualists" into socially engaged persons. Such people are prerequisite not only for progress but, Kilpatrick posits, for survival itself. "The excellence," Kilpatrick asserts, "if not the very existence of our civilization is at stake. We cannot refuse. We must carry on" (p. 118).

Can curriculum content and structure - specifically teacher education curriculum content and structure - encourage such subjective and social reconstruction? Perhaps, but not predictably so: to count on it - as Phelan appreciates - reinscribes the instrumentality that devalues lived experience, wherein educational experience devolves into a means to an ends rather than important in itself. Kilpatrick would question my invocation of "important in itself," associating that idea with what he and other early twentieth-century progressives dismissed as "traditional education," a series of school subjects (like Latin) and instrumental methods (recitation and memorization) that were, in progressives' assessment, anything but intrinsically important. Like Phelan (2015, p. 31), I endorse study as important, and not only (although especially) in the context of a pervasive instrumentalism in the service of a predatory corporatism and education as employability (Pinar, 2015b, pp.11-24). Yes, context is crucial, as it structures one's sense of what must comes next, but there are activities - such a study - that are educationally important no matter where and when they occur. What and how to study vary, but study remains constant as the passage to subjective and social reconstruction.

What varies and what remains? While Kilpatrick's historical moment differs dramatically from ours - and the now is perhaps always temporally heterogeneous ${ }^{49}$ - there are through-lines. Both Kilpatrick and Phelan find themselves attempting to teach against conformity, in Kilpatrick's time against authoritarian teaching, unquestioned classroom rituals, and profoundly anti-democratic forces at home and abroad. Then, like now, as Phelan (2015) notes, "teacher education does little to harness the thought, idealism, and enthusiasm of teacher candidates toward participation in the public sphere" (p. 155). That infinitive "harness" - can mean "to yoke," but it can also mean, Phelan (2015, p. 155) points out, "to make use of (natural resources), especially to produce energy." It seems we have not abandoned altogether the educational project of producing subjectivities, in our time and place aspiring to produce "teachers [who] are able to stand alone, together" (Phelan 2015, p. 155). Concrete, actually existing individuals - alone and together - remain our last resort in cultures of intensifying objectification. Kilpatrick's project remains relevant, the opening epigraph also serving as postscript.

\section{References}

Bobbitt, F. (1918). The curriculum. Boston, MA: Houghton Mifflin.

\footnotetext{
${ }^{49}$ See Dinshaw, C. (2012). How soon is now? Medieval texts, amateur readers, and the queerness of time. Durham, NC: Duke University Press (p. 183, n. 129).
} 
Bruno-Jofré, R., \& Cole, J. (2014). To serve and yet be free: Historical configurations and the insertions of faculties of education in Ontario. In R. Bruno-Jofré \& J. S. Johnson (Eds.), Teacher education in a transnational world (pp. 71-95). Toronto, ON: University of Toronto Press.

Bruno-Jofré, R., \& Johnston, J. S. (Eds.). (2014). Teacher education in a transnational world. Toronto, ON: University of Toronto Press.

Cremin, L. A. (1961). The transformation of the school: Progressivism in American education, 1876-1957. New York, NY: Alfred A. Knopf.

Hirsch, Jr., E. D. (1999). The schools we need: And why we don't have them. New York, NY: Anchor Books.

Huebner, D. E. (1999). The lure of the transcendent. New York, NY: Lawrence Erlbaum.

Jay, M. (2005). Songs of experience: Modern American and European variations on a universal theme. Berkeley, CA: University of California Press.

Jung, J.-H. (in press). The concept of care in curriculum studies. New York, NY: Routledge.

Kilpatrick, W. H. (1918). The project method. Teachers College Record, 19(4), 319-335. [Pages are missing from the Bulletin and there are, in their place, photocopied pages from the original TC Record article. Citations to pages 321, 322, and 323 refer to the original article.]

Kilpatrick, W. H. (1930). Our educational task: As illustrated in the changing South. Chapel Hill, NC: University of North Carolina Press.

Kilpatrick, W. H. (1932). Foreword. In H. Taba's The dynamics of education (pp. xi-xvi). New York, NY: Harcourt, Brace and Company.

Klafki, W. (2000). The significance of classical theories of Bildung for a contemporary concept of Allgemeinbildung. In I. Westbury, S. Hopmann, \& K. Riquarts (Eds.), Teaching as a reflective practice: The German Didaktik tradition (pp. 85-107). Mahwah, NJ: Lawrence Erlbaum.

Kliebard, H. (1986). The struggle for the American curriculum, 1893-1958. Boston, MA: Routledge \& Kegan Paul.

Kridel, C., \& Bullough, Jr., R. V. (2007). Stories of the eight-year study: Reexamining secondary education in America. Foreword by J. I. Goodlad. Albany, NY: State University of New York Press.

Labaree, D. F. (2004). The trouble with Ed schools. New Haven, CT: Yale University Press.

Lee, Y. (2003). Politics and theories in the history of curricular reform in South Korea. In W. F. Pinar (Ed.), The international handbook of curriculum research (pp. 541-552). Mahwah, NJ: Lawrence Erlbaum.

Miller, J. L. (2005). The sounds of silence breaking and other essays: Working the tension in curriculum theory. New York, NY: Peter Lang.

Perlstein, D. (2000). 'There is no escape ... from the ogre of indoctrination': George Counts and the civic dilemmas of democratic educators. In L. Cuban \& D. Shipps (Eds.), 
Reconstructing the common good in education: Coping with intractable dilemmas (pp. 51-67). Stanford, CA: Stanford University Press.

Phelan, A. (2015). Curriculum theorizing and teacher education: Complicating conjunctions. London, England, and New York, NY: Routledge.

Pinar, W. F. (2012). What is curriculum theory? (2nd ed.). New York, NY: Routledge.

Pinar, W. F. (2013). Curriculum studies in the United States. Intellectual histories, present circumstances. New York, NY: Palgrave Macmillan.

Pinar, W. F. (Ed.). (2014). Curriculum studies in China. New York, NY: Palgrave Macmillan.

Pinar, W. F. (2015a). Without experience is teacher development possible? In Z. Hua \& W. F. Pinar (Eds.), Teacher development in China: Subjectivity and culture in curriculum studies (pp. 179-192). New York, NY: Palgrave Macmillan.

Pinar, W. F. (2015b). Educational experience as lived: Knowledge, history, alterity. New York, NY: Routledge.

Pinar, W. F., Reynolds, W. M., Slattery, P., \& Taubman, P. M. (1995). Understanding curriculum: An introduction to historical and contemporary curriculum discourses. New York, NY: Peter Lang.

Pratt, C. (1926). Curriculum-making in the city and country school. In G. M. Whipple (Ed.), The twenty-sixth yearbook of the National Society for the Study of Education: The foundations and technique of curriculum-construction. Part I: Curriculum-making: Past and present (pp. 327-332). Bloomington, IL: Public School Publishing Company.

Ravitch, D. (2000). Left back: A century of battles over school reform. New York, NY: Simon and Schuster.

Reyhner, J., \& Eder, J. (2004). American Indian education: A history. Norman, OK: University of Oklahoma Press.

Rugg, H. (1926). Curriculum-making in laboratory schools. In G. M. Whipple (Ed.), The twentysixth yearbook of the National Society for the Study of Education: The foundations and technique of curriculum-construction. Part I: Curriculum-making: Past and present (pp. 83-112). Bloomington, IL: Public School Publishing Company.

Spring, J. (2006). Pedagogies of globalization: The rise of the educational security state. Mahwah, NJ: Lawrence Erlbaum.

Taba, H. (1932). The dynamics of education. A methodology of progressive educational thought. Foreword by W. H. Kilpatrick. New York, NY: Harcourt, Brace and Company.

Taba, H. (1962). Curriculum development: Theory and practice. New York, NY: Harcourt, Brace \& World, Inc.

Taubman, P. M. (2009). Teaching by numbers: Deconstructing the discourse of standards and accountability in education. New York, NY: Routledge.

Tomkins, G. S. (1986). A common countenance: Stability and change in the Canadian curriculum. Scarborough, ON: Prentice-Hall. [Reprinted in 2008 by Pacific Educational Press, Vancouver, BC.] 
Watkins, W. H. (2006). Social reconstruction in education: Searching out black voices. In K. L. Riley (Ed.), Social reconstruction: People, politics, perspectives (pp. 211-233). Greenwich, CT: Information Age Publishing.

Westbrook, R. (1991). John Dewey and American philosophy. Ithaca, NY: Cornell University Press.

Williamson, B. 2013. The future of the curriculum: School knowledge in the digital age. Cambridge, MA: MIT Press.

Young-Bruehl, E. (1996). The anatomy of prejudices. Cambridge, MA: Harvard University Press. 